\title{
Municipal Waste Management in Poland Compared to Other European Union Countries
}

\author{
Gospodarka odpadami komunalnymi w Polsce w porównaniu do innych państw Unii \\ Europejskiej
}

\author{
Agnieszka Poniatowska ${ }^{1}$, Monika Kisiel ${ }^{1}$, Damian Panasiuk ${ }^{2}$ \\ ${ }^{1}$ Faculty of Biology and Environmental Sciences, Cardinal Stefan Wyszyński University in Warsaw, Poland \\ ${ }^{2}$ Institute of Economics and Finance, Cardinal Stefan Wyszyński University in Warsaw, Poland \\ ORCID AP https://orcid.org/0000-0001-7527-8021; MK https://orcid.org/0000-0002-1613-1094; DP https://orcid.org/0000-0002-7959-984X \\ - a.poniatowska@uksw.edu.pl \\ Received: 14 Oct, 2021; Revised: 24 Nov, 2021; Accepted: 6 Dec, 2021
}

\begin{abstract}
The paper discusses the current state of municipal waste management in Poland, compared to other European Union countries. It indicates the amounts of municipal waste generated over the last few years in Poland and other EU countries. The paper compares waste treatment methods in Poland and Europe, such as recycling, composting, thermal treatment, and waste disposal. An analysis of municipal waste processing installations in Poland is presented. The trends in the municipal waste management system in recent years, have also been described. In the field of municipal waste management in Poland, there have been significant changes. The amount of waste sent to landfills has decreased, and the amount of waste recovered and recycled has increased. These changes are positive and reflect the development of municipal waste management systems in other EU countries. The article indicates the problems and directions of changes in the field of municipal waste management in Poland in the coming years, especially in the context of the implementation of circular economy assumptions and the goals set by the European Union, in terms of increasing the level of waste recycling and reducing its disposal.
\end{abstract}

Keywords: municipal waste, waste management, circular economy, recycling

Streszczenie: Artykuł omawia aktualny stan gospodarowania odpadami komunalnymi w Polsce w porównaniu do innych państw Unii Europejskiej. Wskazuje ilości wytwarzanych odpadów komunalnych na przestrzeni ostatnich kilku lat w Polsce i w pozostałych krajach unijnych. W pracy porównano sposoby zagospodarowania odpadów w Polsce i Europie, takie jak: recykling, kompostowanie, termiczne przetwarzanie i składowanie odpadów. Przedstawiono analizę instalacji do przetwarzania odpadów komunalnych w Polsce. Opisano też tendencje w systemie gospodarowania odpadami komunalnymi w ostatnich latach. W zakresie gospodarowania odpadami komunalnymi w Polsce nastąpiły znaczące zmiany w tym zakresie. Spadła ilość odpadów kierowanych na składowiska, a wzrosła ilość odpadów poddawanych odzyskowi i recyklingowi. Zmiany te są pozytywne i odzwierciedlają rozwój systemów gospodarowania odpadami komunalnymi w innych państwach UE. Artykuł wskazuje problemy i kierunki zmian w zakresie gospodarowania odpadami komunalnymi w Polsce w najbliższych latach, zwłaszcza w kontekście realizacji założeń gospodarki o obiegu zamkniętym i celów wyznaczonych przez Unię Europejską w zakresie wzrostu poziomu recyklingu odpadów i ograniczenia ich składowania.

Słowa kluczowe: odpady komunalne, gospodarka odpadami, gospodarka o obiegu zamkniętym, recykling 


\section{Introduction}

Human activity is always associated with the generation of waste. An important issue is its proper collection and management. In the correct hierarchy of waste management, the most important thing is to prevent its formation, then re-use, recycling, then recovery, and finally disposal of waste. $\mathrm{Mu}-$ nicipal waste can be a resource. In the case of waste disposal, we lose their material potential, or the energy contained in them. The main challenge in waste management, in the coming years, is the transition to a circular economy, the aim of which is to prevent waste generation, and use the potential of waste during its recycling.

In Poland, municipalities are the owners of municipal waste, and they decide how the system of managing municipal waste collected from their area is built. They are the bodies responsible for the supervision and control of this system. By means of a tender, they choose an entrepreneur, who collects and manages the waste. They implement statutory requirements, as regards the level of recovery, recycling of municipal waste, and limiting its landfilling. In the previous period, there have been significant changes in the field of municipal waste management. The amount of waste sent for landfilling has decreased, and the level of recovered and recycled wastes has increased. Several plants for thermal treatment (incineration) of municipal waste, and many installations for mechanical-biological treatment of these wastes have been built, as well as waste composting plants and methane fermentation plants.

These trends are positive and reflect the development of municipal waste management systems in other, more developed, countries of the European Union. In the coming years, it will be necessary to change the national policy in the field of municipal waste management, which would increase the emphasis on waste prevention, development of a circular economy, and raising environmental awareness of the society. It can be hoped that this will allow our country to fulfill its obligations towards the EU, in terms of increasing levels of waste recovery and recycling in the coming years. Proper municipal waste management, based on the correct waste hierarchy, is an important factor influencing the use of natural resources and sustainable, economic growth of the state. In the European Union countries, economic instruments are used in waste management: eco-chargers for waste collection and landfilling, deposit refund systems (glass and plastic bottles, batteries and accumulators, car tyres and bodies), product chargers, as well as subsidies for the construction of landfills (Wasiuta 2015, 231-239). The purpose of this paper is to compare municipal waste management in Poland with the European Union, in the context of key indicators in this area, including waste generation, waste processing with various methods, and showing directions for the future in this aspect. The research for the paper was based on the analysis and compilation of statistical data, published by Eurostat at the European Union level, and the Polish Central Statistical Office data on waste management indicators in Poland.

\section{Amounts of municipal waste generated}

The production of municipal waste in the world in the year 2016, amounted to over 2 billion $\mathrm{Mg}$, of which, the European Union produced about 250 million $\mathrm{Mg}$, accounting for approximately $12 \%$ of global production. According to World Bank forecasts, global municipal waste generation will increase by half, by the year 2050, if no additional measures are taken (Veriks Maplecroft 2019, 5; Jarząbek, Juszczak i Szpor 2020, 11). In Poland, according to data from the Central Statistical Office (GUS), in 2019, nearly 127 million Mg of total waste was generated, of which municipal waste accounted for approximately 10\% (12.8 million $\mathrm{Mg}$ ). There was an almost $6 \%$ increase, compared to the year 2010. This means an increase in the amount of municipal waste generated in Poland per capita, from $316 \mathrm{~kg}$ in 2010, 
to $336 \mathrm{~kg}$ in 2019 (GUS 2020, 149). Figure 1 shows changes in the amount of municipal waste per capita in the EU-27 countries, including Poland, in the years, 2010-2019 (Eurostat Statistics, 2021). There is a visible increase in the amount of municipal waste generated in Poland. However, this indicator is still one of the lowest in Europe, as the average amount of municipal waste per capita, in the EU in 2019, was $502 \mathrm{~kg}$. Economic development and the level and patterns of consumption are the main determinants of the amount of waste generated. The highest amounts of municipal waste per capita were generated by countries with high-level welfare services: Denmark (84.4 kg) and Luxembourg (791 kg). The lowest figures were produced by Romania $(28 \mathrm{o} \mathrm{kg})$ and Estonia $(369 \mathrm{~kg})$. There are differences between countries in the level of collection and management of waste from trade and administration, along with household waste.

Moreover, the inhabitants of Poland are still at a much lower standard of living and consumption, compared to the inhabitants of other more developed European countries. It is usually assumed that the amount of waste generated, increases with the increasing wealth of the society. However, the stage of growth is followed by the stage of the so-called "saturation", above which, the amount of waste is already stabilised. Unfortunately, in Poland, despite the increase in the national income, the amount of municipal waste generated has not changed significantly, in recent years (Andrzejewska 2019, 14). This is an abnormal trend, different from the underlying trends in other European countries.

The low value of this indicator in Poland, may result from leaks in the municipal waste management system. It may probably be caused by diverting some of the received waste outside the collection system, e.g., to illegal landfills, or by classifying waste in codes other than municipal waste, by waste collectors. Nearly 70\% of households in Poland use solid fuels (coal, wood) as the main heat source. With the beginning of the heating season, the highest concentrations of PM10, PM2.5 and benzo[a] pyrene are recorded in Poland. This corresponds to the increased level of smog during the heating season, especially in regions where solid fuel stoves are still used, often using poor-quality coal and, unfortunately, illegal waste (Wielogosiński 2016, 1213; Guła 2016, 74-76). However, more and more municipalities check the inhabitants for irregularities in this regard, and many programmes have been created to finance the replacement of old coal-fired furnaces. In addition, there is a growing interest in implementation of renewable energy sources. Therefore, it can be expected that the phenomenon of illegal waste incineration in

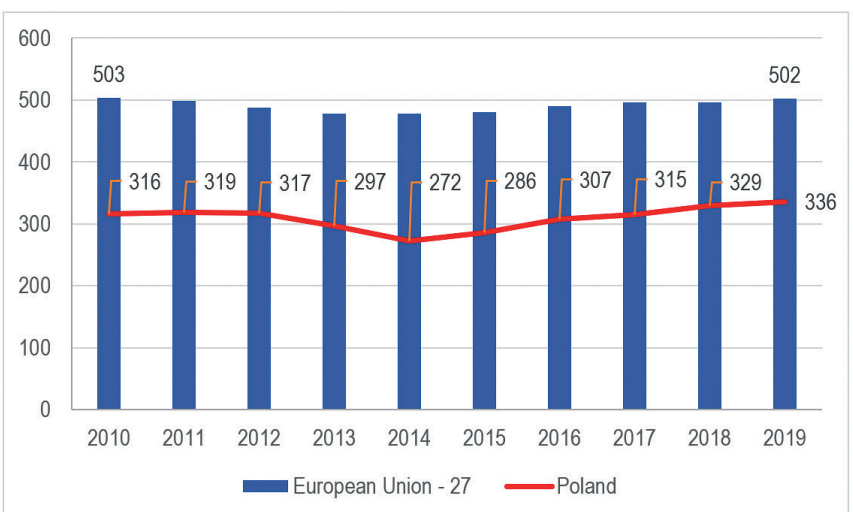

Figure 1. Comparison of the amount of waste generated per capita in the EU-27 countries and Poland, in the years, 2010-2019 (based on Eurostat Statistics 2021) 
domestic furnaces will be eliminated over time. The role of the commune as the system manager is important here, so that, with proper control of both, the entity responsible for the collection and management of waste, as well as the residents, will diagnose and eliminate these irregularities in waste management.

The amount of municipal waste generated, depends on the number of people in a given area, as well as the level of consumption. In the western and central provinces, i.e., in the richer regions of Poland, much more municipal waste is generated per capita than in the eastern provinces. The majority of municipal waste collected in Poland in 2019, was waste from residents $-83.3 \%$, which accounted for 9.9 million $\mathrm{Mg}$. The remaining collected waste came from municipal companies and services (1.9 million $\mathrm{Mg}$ ). Municipalities usually do not take advantage of the possibility of covering both residents and companies operating in their area, with the waste collection system, and usually organise waste collection, only for their residents (GUS 2020, 155).

\section{Processing of municipal waste in Poland}

In Poland, $56 \%$ of the total waste collected in 2019, was sent for recovery (material recycling $-25 \%$, composting $-9 \%$, incineration with energy recovery $-23 \%)$. When it comes to neutralisation, which is the least recommended way of waste management, $43 \%$ of the waste was directed to landfills (Figure 2). Even 10 years ago, landfilling was the dominant method of municipal waste treatment in Poland. $86 \%$ of waste was managed in this way, $12 \%$ of waste was recycled, only $2 \%$ of waste was composted, and practically, no waste was incinerated (Eurostat Statistics 2021). For comparison, in the world in the year 2015 , as much as $70 \%$ of waste was landfilled, with only $13 \%$ recycled, $11 \%$ incinerated and 6\% composted (Kaza 2018, 34).

In recent years, Poland has experienced a great growth of municipal waste management costs. This was due to an increase in the cost of waste collection and transportation, (e.g., increase in the number of fractions to be collected by households), and an increase in the management costs system (salary costs and new fire regulations for installations). Costs of waste processing have also increased, recently, due to the increase in the costs of calorific waste management, adaptation to new regulations (BAT requirements, securing claims, video surveillance, and new fire protection regulations) (IOŚ 2021, 27).

\subsection{Recycling of municipal waste}

Figure 3. shows the amounts of waste sent for material recycling of municipal waste per capita in the EU-27 countries, and Poland, in the years, 2010-2019. This level in Poland has doubled in the last 10 years. In 2019, compared to the EU average $(152 \mathrm{~kg} / \mathrm{in}$ habitant), Poland obtained a low level of recycled waste $-84 \mathrm{~kg} /$ inhabitant, in total it was 3.2 million $\mathrm{Mg}$. The best in this respect was its neighbour, Germany, which achieved

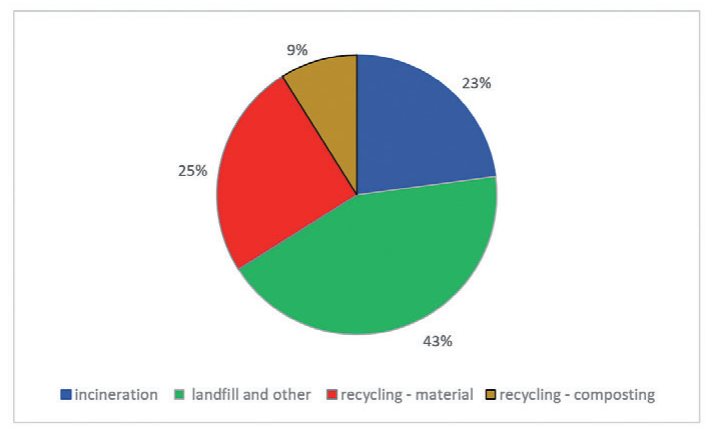

Figure 2. Share of municipal waste treatment methods in Poland, in the year 2019 (based on Eurostat Statistics 2021) 
the highest level - $292 \mathrm{~kg} /$ inhabitant. This shows how much we still have to do in the country, when it comes to the amount of waste sent for recycling. Waste should be treated as secondary raw materials. The degree of recycling depends largely on the amount of selectively collected waste, so the tendency of this indicator to increase from year to year in Poland is positive. In 2019, nearly 4 million $\mathrm{Mg}$ of waste was collected selectively, and over the last 10 years, this amount has increased five times, related to the fact that municipalities took over the organisation of municipal waste collection from residents in 2013. Moreover, the cost of collecting waste gathered selectively, was lower for residents than the cost of collecting waste gathered together, therefore, there has been a growing tendency in separate waste collection. In addition, the increase in this indicator was influenced by the amendment to the law, according to which, the obligation of selective collection of municipal waste by property owners was introduced by all municipalities (Ustawa 1996, art. 3; Rozporządzenie 2021, $\mathbb{\$} 1$ ).

In 2019, there were 2,190 public, accessible, municipal waste, separate collection points for residents in Poland, most of which were located in rural areas (63\%) (GUS 2020, 157). In 2018, Poland achieved a $36 \%$ level of preparation for re-use and recycling of municipal waste, compared to the $30 \%$ required by the then applicable law (Rozporządzenie 2016; Senat.gov. pl 2020). Therefore, Poland faces major challenges, taking into account the target set for the year 2035, in the amount of $65 \%$ of municipal waste sent for recycling (Ustawa 1996, art. 3b, ust. 1). Therefore, source separation of waste is a fundamental element in the further efficient processing of waste as raw materials. The inhabitants should still be educated in the field of proper segregation of waste, and individual properties should be controlled in this respect.

\subsection{Composting of municipal waste}

When it comes to composting waste, a lot has been done in this area in Poland in the last 10 years, as this level has increased 6 times. In total, 1.2 million $\mathrm{Mg}$ of waste were subjected to organic recycling in 2019. However, Poland is still at a very low level $(30 \mathrm{~kg} /$ inhabitant), compared to the EU average of $87 \mathrm{~kg} /$ inhabitant (Eurostat Statistics 2021, see Figure 4).

Poland has much to do here, as it is necessary to increase the amount of separately collected bio-waste, and to build installations processing bio-degradable waste. Polish municipalities are obliged to carry out selective collection of bio-degradable waste, which should increase the amount of organic waste and increase the level of organic recycling (Ustawa 1996, art. 3.1). In addition, one of the goals set out in the $\mathrm{Na}$ tional Waste Management Plan (KPGO) up to 2022 , is to promote bio-waste treatment technologies that will result in the production of material used for fertilisation or rehabilitation purposes (KPGO 2016, 105). Due

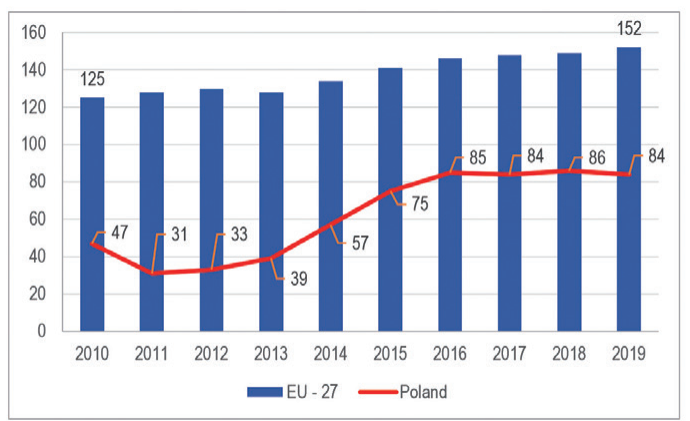

Figure 3. Comparison of material recycling of municipal waste per capita (kg per person) in the EU-27 countries and Poland, in the years, 2010-2019 (based on Eurostat Statistics 2021) 


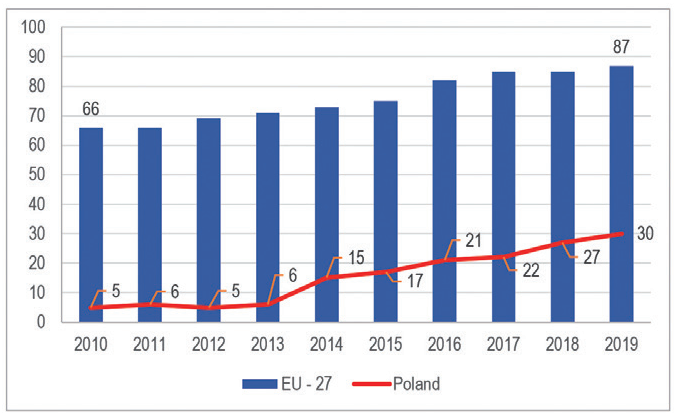

Figure 4. Comparison of municipal waste composting per capita (kg per person) in the EU-27 countries and Poland, in the years, 2010-2019 (based on Eurostat Statistics 2021)

to the plans to implement the provisions related to the EU policy of the circular economy, and the plans included in the KPGO, an increase in the amount of bio-degradable waste collected and biologically transformed in Poland, can be expected in the coming years.

\subsection{Incineration of municipal waste}

In recent years, the level of thermally processed municipal waste in Poland has increased, significantly. In 2019, approximately $23 \%$ of waste was sent for thermal processing. It was 2, 920 thousand. $\mathrm{Mg}$ of waste, which per capita, amounted to $77 \mathrm{~kg}$, with the $\mathrm{EU}$ average being almost twice as high at -134 $\mathrm{kg}$ /inhabitant (Eurostat Statistics 2021, see Figure 5). Recently, there has been a major progression in this regard, due to the construction of several incineration plants.

Currently, there are 9 thermal waste processing plants in Poland (Białystok, Bydgoszcz, Konin, Poznań, Kraków, Warsaw, Szczecin, Rzeszów, and Zabrze). It is planned to build more installations, including in Oświęcim, Gdańsk, and an expansion of the installation in Warsaw. By way of comparison, there are 66 incineration plants in Germany (Szymański 2021). The increase in the amount of waste sent for incineration was also influenced by the prohibition (effective from January 1, 2016) of landfilling waste after mechanical treatment and municipal waste, for which the heat of combustion is above $6 \mathrm{MJ} / \mathrm{kg}$ (Rozporządzenie 2015).

\subsection{Disposal of municipal waste}

In 2019 , approximately $43 \%$ of waste in Poland was disposed of in landfills. It was a total of 5.5 million $\mathrm{Mg}$. In comparison to previous years, when waste disposal was the dominant method, it is a very positive trend (in 2010, as much as $73 \%$ of waste was stored - 7.4 million Mg). Landfilling is a method that has been abandoned in most European countries. However, there are countries, e.g., Malta, Cyprus, Greece, where landfilling is still the dominant method of their processing. Poland with 145 $\mathrm{kg} /$ inhabitant is at a similar level of landfilling as the EU average, see Fig. 6.

The reduction in the amount of waste going to landfills can be attributed to the implementation of European legislation, e.g., tightening criteria and procedures for acceptance of waste at landfills. In Poland, these regulations have been in force since the beginning of 2016, and were introduced by the ordinance of the Minister of Economy, on the acceptance of waste for storage, pursuant to which, a ban on the storage of waste after mechanical treatment and municipal waste, for which the heat of combustion is above $6 \mathrm{MJ} / \mathrm{kg}$, was introduced (Rozporządzenie 2015, art. 3). This means that municipal waste must be treated in a way other than landfilling. The package of changes in EU law, aimed at implementing the circular economy, assumes a significant reduction in waste disposal (landfilling to a maximum of $10 \%$ by the year 2035 ) in 


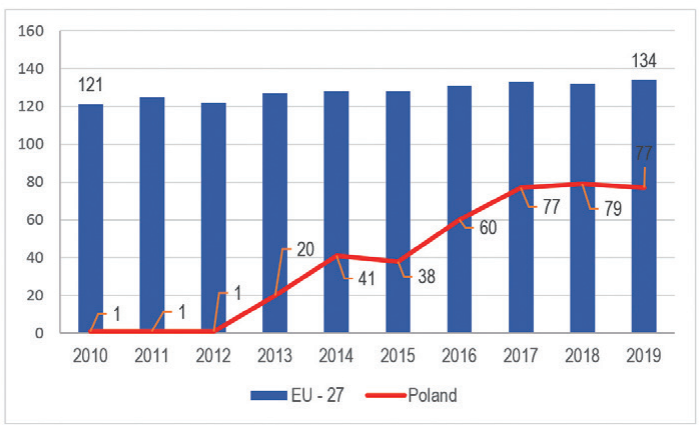

Figure 5. Comparison of incineration of municipal waste per capita (kg per person) in the EU-27 countries and Poland, in the years, 2010-2019 (based on Eurostat Statistics, 2021)

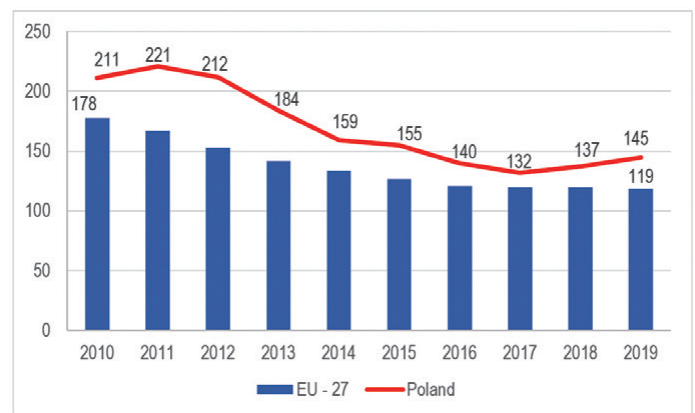

Figure 6. Comparison of municipal waste landfilling per capita (kg per person) in the EU-27 countries and Poland in the years, 2010-2019 (based on Eurostat Statistics, 2021)

favour of preparation for re-use and recycling (Dyrektywa 2018/850/EU, art. 1).

Due to the necessity to adapt municipal waste landfills to the legal requirements, the number of landfills has been systematically decreasing for several years. At the end of 2019, there were 278 municipal waste disposal sites in Poland, covering a total area of 1,670 ha (approximately 600 landfills were in operation in 2010). In 2019, 16 landfills with a total area of 52.8 ha were closed (GUS 2018, 25; GUS 2020, 159).

\section{Directions of changes in the municipal waste management system in Poland}

The directions of changes in the municipal waste management system in Poland for the coming years have been defined in strategic documents, e.g., in the National Waste Management Plan (KPGO). The priority issues in this document include: waste prevention, reducing the amount of landfilled waste, achieving the required level of recycling and preparing municipal waste for re-use (KGPO 2016, 7-9). In addition, the package of amendments to the European Commission's directives, associated with the circular economy, defined goals and directions in waste management for the coming years, indicating an increase in the levels of recovery and recycling of municipal waste to $65 \%$, and a significant reduction in municipal waste landfilling, below $10 \%$ by weight generated municipal waste by the year 2035 . Member States were also obliged to establish a separate system for the collection of textiles and hazardous waste from households, by January 1, 2025. By the end of the year 2023, bio-waste will have to be collected separately, and subject to the so-called recycling at source, in home composters (Ustawa 1996, art. 4.2.; Dyrektywa 2018/851/EU art. 11; Dyrektywa 2018/850/EU; Komunikat 2018). Moreover, the circular economy will be the key direction for the future in municipal waste management. In Poland, they are 
defined in the Roadmap for transformation towards a circular economy (Mapa Drogowa $2019,22)$, as a concept, in which the value of products, materials, and raw materials should remain in circulation for as long as possible, and the generation of waste should be minimised as much as possible, and the resulting waste should be managed, in accordance with the hierarchy of waste management methods.

EU regulations also impose on the Member States, the introduction of the so-called Extended Producer Responsibility (EPR), in which economic operators should participate in the costs and organisation of waste management, resulting from their products. Currently, the Ministry of Climate and Environment in Poland is analysing the comments, collected during public consultations, regarding the draft amendment to the Act on the management of packaging and packaging waste, which is to introduce the ERP system in Poland (Pietrzyk 2021). Apart from packaging, EPR will also apply to electrical and electronic equipment, vehicles, batteries, accumulators, tyres, and oils. The EPR is to encourage manufacturers to introduce changes, in the way products are designed and manufactured. As a result, the amount of waste produced should decrease, and after the product life of the products, the waste generated from them, will be more easily recycled. The funds obtained from the EPR mechanism would cover the costs of waste collection and management, so, it would be possible to limit the increase in fees paid by residents, under municipal waste management systems, and also to finance recycling infrastructure. The assumptions of the EPR, are in line with the objectives of the circular economy (Przemysł i Środowisko 2021).

Bearing in mind Poland's long-term waste management goals, municipal waste management should focus on increasing the quantity and quality of separately collected waste, increasing the recycling rate of raw material waste, recycling biowaste, and incineration of residual waste with energy recovery (Poniatowska 2019; Rozporządzenie 2021).

\section{Summary and Conclusions}

In recent years, municipal waste management in Poland has changed significantly. Waste landfilling is being abandoned in favour of its recovery, mainly in municipal installations, waste composting plants, recycling plants, and thermal waste treatment installations. From year to year, the amount of municipal waste collected, selectively, and the level of recycling increases. When it comes to problems in the municipal waste management system in Poland, the rates for collecting waste from residents have recently been increasing. The reason for this is the increased costs of waste management. Currently, the dominant technology for the processing of mixed municipal waste is mechanical-biological processing (MBP) installations. For several years, there has been a problem with the management of waste from these installations, especially with calorific waste and sorting residues. These fractions are directed to cement plants or thermal treatment plants. Cement plants set high requirements for the received fuels, which alternative fuels, produced in MBP installations, do not obtain. There are also insufficient, processing capacities of several thermal waste treatment plants currently operating in Poland. The management of this waste is also difficult, due to the impossibility of its storage, at a calorific value exceeding $6 \mathrm{MJ} / \mathrm{kg}$ (Rozporządzenie 2015). This causes blockages in the transfer of waste, and a constant increase in the prices of their disposal. In recent years, there have been numerous fires in waste processing installations, which also indicate serious problems with their proper management. Unfortunately, most of the waste generated, as a result of biological treatment, was deposited in landfills, which is not a positive trend (NIK 2020).

To solve the problem with the management of waste from MBP installations, local governments indicate the possibility 
of modernising the existing heat and power plants, in order to supply them with fuel from waste (Prezes RM 2020). However, further possible directing of the municipal waste stream to thermal waste treatment, should depend on the degree to which municipalities achieve recycling levels. Communes and voivodeship marshals, as authorities responsible for waste management planning, should analyse and monitor this level on an annual basis, so that there is no threat to the achievement of the levels of municipal waste recycling, required by European Union law. Work is currently underway on the provisions on extended producer responsibility (EPR), which should increase the mass of waste sent for recycling, which in turn, will reduce the amount of waste that can be processed, as a result of thermal treatment (Prezes RM 202O).

The overriding goal and direction of municipal waste management in Poland for the future, is to increase the amount of separately collected waste, including bio-degradable waste, and to direct it to recycling plants. As for the infrastructure of municipal waste management plants in Poland, unfortunately, it is simply not sufficient at the moment. It is necessary to build more composting plants, bio-degradable waste fermentation plants, and installations for the management of energy fractions, e.g., local heat and power plants powered by waste. However, in accordance with the circular economy implemented in the country, thermal conversion should complement the comprehensive municipal waste management system (Prezes RM 2020). On the other hand, the existing MBP installations should be modernized in the mechanical part in order to increase the production of recyclable waste and the biological part, thanks to which the level of organic recycling will increase.

Poland faces major challenges in the coming years, in terms of increasing the amount of waste directed for recycling, reducing landfilling, and implementing the EPR. Moreover, a key direction in municipal waste management in Poland, will be the transition to a circular economy in the coming years. The reduction in the amount of municipal waste generated, should be influenced by a change in the national policy, which will increase the emphasis on preventing and reducing waste generation, and further increasing the environmental awareness of the society.

Author Contributions: Conceptualisation, A.P.; Resources, A.P., M.K. and D.P.; Writing - Original Draft Preparation, A.P.; Writing - Review \& Editing, A.P., M.K. and D.P. Authors have read and agreed to the published version of the manuscript.

Funding: This research received no external funding. Institutional Review Board Statement: Not applicable.

Conflicts of Interest: The authors declare no conflict of interest.

\section{References}

Andrzejewska-Górecka Dorota, Anna, Ewa Duchnowska, i Agnieszka Poniatowska. 2019. Potencjat wykorzystania biotechnologii w zarzadzaniu odpadami $w$ Polsce. [The potential of using biotechnology in waste management in Poland]. Warszawa: Polski Instytut Ekonomiczny. https://pie.net.pl/wp-content/uploads/2018/07/ PIE-Biotechnologia.pdf.

Dyrektywa 2018/850/UE - Dyrektywa Parlamentu Europejskiego i Rady (UE) 2018/850 z dnia 30 maja 2018 r. zmieniajaca dyrektywę 1999/31/ WE w sprawie sktadowania odpadów. [Directive (EU) 2018/850 of the European Parliament and of the Council of 30 May 2018 amending Directive 1999/31/EC on the landfill of waste]. (OJ L 150, 14.6.2018, 100-108)

Dyrektywa 2018/851/UE - Dyrektywa Parlamentu Europejskiego i Rady (UE) 2018/851 z dnia 30 maja 2018 r. zmieniajaca dyrektywe 2008/98/ WE w sprawie odpadów. [Directive (EU) 2018/851 of the European Parliament and of the Council of 30 May 2018 amending Directive 2008/98/EC on waste]. (OJ L 150, 14.6.2018, 109-140).

Eurostat Statistics. 2021. "Municipal waste by waste management operations." Accessed 4.12.2021 https://ec.europa.eu/eurostat/cache/metadata/ en/env_wasmun_esms.htm. 
Guła, Andrzej, i Łukasz Pytliński. 2016. "Niska emisja - palący problem polskich domów." [Low emissions - a pressing problem of Polish households]. W Zrównoważone miasta. Życie $w$ zdrowej atmosferze. [Sustainable cities. Living in a healthy atmosphere], red. Maksymilian Mazurkiewicz, Anna Lewicka, Daria Mikołajska, Justyna Mazurek, 73-81. Warszawa: Global Compact Poland. http://obserwatorium.miasta. $\mathrm{pl} / \mathrm{wp}$ - content/uploads/2016/10/RaportZr\%C3\%B3wnowa\%C5\%BCone-miasta.pdf.

GUS (Główny Urząd Statystyczny). 2020. Ochrona Środowiska 2020. [Environmental Protection 2020]. https://stat.gov.pl/obszary-tematyczne/ srodowisko-energia/srodowisko/ochronasrodowiska-2020,1,21.html.

GUS (Główny Urząd Statystyczny). 2018. Infrastruktura komunalna w $2017 \quad r$. [Municipal infrastructure in 2017]. https:// stat.gov.pl/files/gfx/portalinformacyjny/pl/ defaultaktualnosci/5492/3/15/1/infrastruktura komunalna_w_2017_r.pdf.

IOŚ (Instytut Ochrony Środowiska). 2021. Gospodarka odpadami komunalnymi w Polsce. Analiza kosztów gospodarki odpadami komunalnymi. [Municipal waste management in Poland. Analysis of municipal waste management costs]. https:// ios.edu.pl/wp-content/uploads/2021/11/55848_ gospodarka_odpadami_3.pdf

Jarząbek, Andrzej, Adam Juszczak i Aleksander Szpor. 2020. Czy zaleja nas śmieci? [Will we be flooded with garbage?] Warszawa: Polski Instytut Ekonomiczny. https://pie.net.pl/wp-content/ uploads/2020/09/PIE-Zalew-smieci.pdf.

Kaza, Silpa, Lisa Yao, Perinaz Bhada-Tata i Frank Van Woerden. 2018. What a Waste 2.0: A Global Snapshot of Solid Waste Management to 2050. Urban Development, World Bank. https://openknowledge.worldbank.org/ handle/10986/30317.

Komunikat 2018 - Komunikat Komisji do Parlamentu Europejskiego, Rady, Europejskiego Komitetu Ekonomiczno-Społecznego i Komitetu Regionów w sprawie monitorowania gospodarki o obiegu zamkniętym. [Communication from the Commission to the European Parliament, the Council, the European Economic and social Committee and the committee of the regions on a monitoring framework for the circular economy]. Accessed 4.12.2021. https://eur-lex.europa.eu/legal-content/pl/txt/ pdf/?uri=celex:52018dc0029\&from=en.

KPGO 2016 - Krajowy plan gospodarki odpadami 2022. [National waste management plan 2022]. (M.P. poz. 784).

Mapa drogowa 2019 - Mapa drogowa transformacji w kierunku gospodarki o obiegu zamkniętym. [Roadmap for transformation towards a circular economy]. Accessed 4.12.2021. https://www.gov.pl/ web/rozwoj-technologia/rada-ministrow-przyjelaprojekt-mapy-drogowej-goz.

NIK (Najwyższa Izba Kontroli). 2020. Informacja o wynikach kontroli: Postępowanie z odpadami komunalnymi po przetworzeniu $w$ instalacjach mechaniczno-biologicznego przetwarzania odpadów komunalnych (MBP). [Information on control results: Treatment of municipal waste after transforming the installation in mechanicalbiological installations for municipal waste (MBP)]. KSI.430.003.2019, Nr ewid. 194/2019/P/19/048/KSI. https://www.nik.gov.pl/plik/id,22514,vp,25194.pdf.

Pietrzyk, Dominika. 2021. "Ustawa o ROP. Ministerstwo nanosi poprawki w projekcie." [The law on EPR. The ministry introduces amendments to the draft]. Dostęp 18.12.2021. https://biznes.interia.pl/gospodarka/newsustawa-o-rop-ministerstwo-nanosi-poprawkiw-projekcie,nId,5655679.

Poniatowska, Agnieszka, Bartłomiej Macherzyński, and Dorota Andrzejewska. 2019. "Zarządzanie gospodarką odpadami komunalnymi na przykładzie gmin w Polsce." [Municipal waste management based on the example of municipalities in Poland]. In Przyszłość dla Biznesu, Biznes dla Przyszłości 2019 [Future for Business, Business for the Future 2019], eds Iwona Herbuś, Aneta Herbuś, i Bartłomiej Macherzyński, 63-74. Częstochowa: Oficyna Wydawnicza Stowarzyszenia Menedżerów Jakości i Produkcji. Prezes RM - Pismo Prezesa Rady Ministrów nr DKPL. WK.10.2.90.2020.JS(13)RM-10-88-20 UD136 $z$ dnia 23.10.2020 r. - dotyczace projektu ustawy $z$ dnia o zmianie ustawy o utrzymaniu czystości i porzadku w gminach oraz niektórych innych ustaw. [Letter of the Prime Minister of 23 October 2020 - regarding the draft act of amending the Act on maintaining cleanliness and order in municipalities and certain other acts]. Accessed 
4.12.2021. http://orka.sejm.gov.pl/Druki9ka.nsf/ Projekty/9-020-307-2020/\$file/9-020-307-2020. pdf.

Przemysł i Środowisko 2021. "ROP i system kaucyjnodepozytowy w zarządzaniu odpadami." [ERP and deposit system in waste management]. Accessed 4.12.2021. https://przemyslisrodowisko.pl/ropi-system-kaucyjno-depozytowy-w-zarzadzaniuodpadami.

Rozporządzenie 2015 - Rozporzadzenie Ministra Gospodarki z dnia 16 lipca 2015 r. w sprawie dopuszczania odpadów do sktadowania na sktadowiskach. [Regulation of the Minister of Economy of 16 July 2015 on allowing waste to be stored in landfills] (Dz.U. 2015 poz. 1277).

Rozporządzenie 2016 - Rozporzadzenie Ministra Srodowiska $z$ dnia 14 grudnia 2016 r. w sprawie poziomów recyklingu, przygotowania do ponownego użycia i odzysku innymi metodami niektórych frakcji odpadów komunalnych. [Regulation of the Minister of the Environment of 14 December 2016 on the levels of recycling, preparation for re-use and recovery by other methods of certain fractions of municipal waste]. (Dz.U. 2016 poz. 2167).

Rozporządzenie 2021 - Rozporzadzenie Ministra Klimatu i Środowiska $z$ dnia 10 maja 2021 r. w sprawie sposobu selektywnego zbierania wybranych frakcji odpadów. [Regulation of the Minister of Climate and Environment of 10 May 2021 on the method of selective collection of selected waste fractions] (Dz.U. 2021 poz. 906). Senat.gov.pl. 2020. Posiedzenie Komisji Środowiska (nr 8) w dniu 04-02-2020. [Meeting of the Environment Committee (No. 8), on 02/04/2020], stenographic record. https:// www.senat.gov.pl/prace/komisje-senackie/ przebieg,8532,1.html.

Szymański, Dominik. 2021. "Spalanie odpadów. Jakie są perspektywy rozwoju rynku paliw alternatywnych?" [Waste incineration. What are the prospects for the development of the alternative fuels market?]. Accessed 4.12.2021. https://portalkomunalny.pl/spalanieodpadow-jakie-sa-perspektywy-rozwoju-rynkupaliw-z-odpadow-419754.

Ustawa 1996 - Ustawa z dnia 13 września 1996 r. o utrzymaniu czystości i porzadku w gminach [The act of 13 September 1996 on maintaining cleanliness and order in municipalities]. (Dz.U. 1996 nr 132 poz. 622, ze zm.).

Veriks Maplecroft. 2019. Waste Generation and Recycling Indices 2019 Overview and findings. https://www.circularonline.co.uk/wp-content/ uploads/2019/07/Verisk_Maplecroft_Waste_ Generation_Index_Overview_2019.pdf.

Wasiuta, Aleksander. 2015. "Ekonomiczne instrumenty polityki ekologicznej w kontekście zarządzania środowiskowego." [Economic instruments of ecological policy in the context of environmental management]. In Wspótdziatanie systemu zarzadzania i inżynierii produkcji. Teoria i praktyka [Interaction of management system and production engineering. Theory and practice], eds Tadeusz Noch and Jan Saczuk, 223-246. Gdańsk: Wydawnictwo Gdańskiej Szkoły Wyższej.

Wielogosiński, Grzegorz, i Olga Namiecińska. 2016. "Spalarnie odpadów komunalnych - perspektywa roku 2020." [Municipal waste incineration perspective for the year 2020]. Nowa Energia 2(50): 11-20. 